\title{
Occupations, Preoccupations, and Political Science
}

\author{
Jeffrey C. Isaac
}

In recent issues of Perspectives, we have sought to highlight the themes of inequality, exclusion, and the challenges facing democratic politics. We have done this because these themes resound throughout the current political world. Economist and Nobel laureate Joseph Stiglitz nicely summed up this state of affairs in a November 4, 2011 column circulated by Project Syndicate: "The protest movement that began in Tunisia in January, subsequently spreading to Egypt, and then to Spain, has now become global, with the protests engulfing Wall Street and cities across America. Globalization and modern technology now enable social movements to transcend borders as rapidly as ideas can. And social protest has found fertile ground everywhere: a sense that the 'system' has failed, and the conviction that even in a democracy, the electoral process will not set things right - at least not without strong pressure from the street." The Occupy movement that spread like wildfire throughout the US, and that asserted itself on some major US university campuses, is simply the latest iteration of this diffusion of protest in which young people from Athens and Madrid to Cairo and Damascus seem to be playing a crucial role.

We believe that political science at its best takes its bearings from such historical developments and furnishes valuable perspectives on and insights into them. And we are pleased to be able to publish some of the very best political science in our pages.

The lead piece in our current issue is Carole Pateman's 2011 APSA Presidential Address, "Participatory Democracy Revisited." Pateman's 1970 Participation and Democratic Theory was a seminal contribution to political science debates about pluralism, power and "democratic elites" that was inspired by the participatory upsurges associated with "1968." In that book, Pateman sought to reconstruct a tradition of thinking about "participatory democracy" as an antidote to the more Schumpeterian approach of so-called "empirical democratic theory." In her 2011 Presidential Address, Pateman reflects on subsequent developments in democratic theory, particularly on theories of "deliberative democracy" and more recent interest in "participatory budgeting" experiments pioneered in Brazil (see our December 2011 review essay by Archon Fung on this topic). Pateman appreciates both the experimentalism and the sometimes radical energies associated with these forms of democratic praxis. At the same time, she is skeptical about their ability, as theorized or as practiced, to substantially challenge entrenched forms of power and privilege in either the global South or the global North. Noting that "the contemporary support for participation by governments, official bodies and NGOs is in striking contrast to participation in the 1960 s, which was championed by popular movements in rich countries," she suggests that "one way of looking at the new expansion of participation is that, in poor countries it can help improve governance, and in rich countries it can help bolster the legitimacy of the present system." Yet, she reminds readers, neither "good governance" nor "legitimacy" is the same as democratic empowerment. She concludes by posing a bracing question: "whether, in the rich countries, there is any longer either the political culture or the political will to pursue genuine democratization."

Genuine democratization. The very turn of phrase expresses a profound truth about contemporary political science and about the contemporary world that this political science seeks to understand-that "democracy" is a powerful signifier, and democratization an overriding preoccupation, and yet both the referents and the very meanings of these concepts are deeply contested and in question. This has been a major theme of many of our recently published pieces, just as it is the theme of "Democratic Imperatives: Innovations in Rights, Participation, and Economic Citizenship," the important report of the Patemanappointed Task Force on Democracy, Economic Security, and Social Justice in a Volatile World.

This issue's lead research article, Andreas Schedler's "Judgment and Measurement in Political Science," is a major contribution to thinking about these questions. Schedler's primary purpose is to address a foundational problem at the heart of empirical political science: the fact that most of what is analyzed is neither directly "observable" nor unproblematic in its measurement. Measurement, he argues, is "an act of translation between concepts and realities in the language of numbers." And the need to validate and justify such translations is as essential to 
empirical political science as is the need to employ appropriate forms of quantitative analysis to the phenomena so measured. Schedler thus insists that "judgment is a critical intersubjective ingredient of political measurement that needs to be acknowledged and rationalized, rather than exorcised." His piece is a very careful discussion of the important methodological challenges of quantitative reasoning that arise in practice, and it serves a constructive programmatic point: "We must not suffocate judgmental elements through finely knitted webs of bureaucratic regulation. But we do need to define demanding common standards and operating procedures in five crucial areas: expert selection, measurement comparability, transparency, convergence, and accountability."

These challenges are particularly germane to debates within the comparative politics of democratization about the "quality" of democracy and the most appropriate means of conceptualizing and measuring this-also the theme of our June 2011 lead article, John Gerring and Michael Coppedge's "Conceptualizing and Measuring Democracy: A New Approach.” And, as Alfred Stepan and Juan Linz made clear in their December 2011 review essay, "Comparative Perspectives on Inequality and the Quality of Democracy in the US," such questions are as relevant to the study of American politics as they are to the study of the politics of everywhere else.

The importance of such questions is accentuated in this issue's second research article, Julia R. Azari and Jennifer K. Smith's "Unwritten Rules: Informal Institutions in Established Democracies." If Schedler is interested in the informal but very important processes by which political scientists measure and explain a dense and complex world, Azari and Smith are interested in the informal rules, processes, and institutions that constitute the political world in all of its density and complexity. By beginning their article with the 2011 political crisis over the Wisconsin budget, they highlight the ways in which the interplay of formal and informal institutions shapes highly contentious contemporary political conflicts centering on distributive politics and on the very legitimacy of the democratic state as an institution with the authority to tax, spend, and deliver public goods through its public employees. As Azari and Smith argue, the Wisconsin crisis-a breakdown in legislative deliberation, and a veritable boycott of the state legislature by minority party legislators that stymied the legislative process, tied the hands of a controversial governor, and fed political protest for and againstexemplifies the role of informal rules in structuring political expectations. "Violation of these expectations," they insist, "can lead to destabilizing conflict, as clashes over policy escalate to clashes over the political process itself." Proceeding from this example, Azari and Smith outline the ways that informal institutions complete, coordinate, and parallel formal institutions, and suggest that the formal/ informal institutional interface is "a site of tension pro- ductive of change in both written and unwritten rules." They then illustrate this argument by discussing four informal institutions in American politics: the two-term norm of presidential service, the norms governing extended debate in the U.S. Senate, the unwritten rules of the presidential nomination process, and the public presidency. They conclude by suggesting that "Americanists may have particular cause to study informal institutions now, for reasons rooted in the contemporary crisis of polarization in U.S. politics."

Sidney M. Milkis, Jesse Hessler Rhodes, and Emily Jane Charnock sound a very similar theme in "What Happened to Post-Partisanship? Barack Obama and the New American Party System." Unlike Wisconsin Governor Scott Walker, President Barack Obama campaigned as a postpartisan (and also post-racial) candidate who represented a new way of doing politics. And yet within months of taking office, Obama became a lightening rod of controversy. And interestingly, the more he has seemed to lean in a post-partisan or at least a bipartisan direction, the more polarizing his Presidency has become. Milkis, Rhodes, and Charnock are interested in explaining why. While they acknowledge the relevance of both economic crisis and racial subtext, they focus their attention on what they call "the new American party system" (a good example of the formal/informal interface discussed by Azari and Smith). Extending themes that they developed in their September 2007 Perspectives article on "George W. Bush, the Republican Party, and the 'New' American Party System," Milkis, Rhodes, and Charnock argue that the dynamics of partisan competition place contemporary presidents in a difficult and perhaps even contradictory position. As they write: "Our central point is that Obama's political difficulties have stemmed from his efforts to reconcile two competing modes of presidential leadership — a venerable method of executive leadership exalting nonpartisan administration of the welfare and national security states, and an emergent style of partisan presidential leadership featuring vigorous efforts to accomplish party objectives-in a context characterized by widespread dissatisfaction with government, strong and intensifying political polarization, and high-stakes battles over the basic direction of domestic and military programs."

Milkis, Rhodes, and Charnock's article underscores the importance of a broadly institutionalist perspective to the understanding of contemporary partisan politics in the US. At the same time, their piece underscores the importance of an even more broadly comparative perspective. For as George Papandreou, Jose Zapatero, and Silvio Berlusconiall recently deposed Prime Ministers of parliamentary systems - can attest, political polarization and crisis are hardly unique to the US, with its distinctive Presidential and party systems. Indeed, as Stiglitz and many others have noted, the combination of global financial crisis and domestic fiscal crisis is testing the political architecture of even the 
most advanced liberal democracies. Our Critical Dialogue between Jeffrey A. Winters and John P. McCormick on their respective books_clearly entitled Oligarchy and Machiavellian Democracy — highlights the challenges currently posed to democracy by economic inequality, a theme that we have recently featured in symposia on Larry Bartels' Unequal Democracy, Jacob Hacker and Paul Pierson's Winner Take All Politics, and "Oligarchy in the United States?" the December 2009 article co-authored by Winters and Benjamin I. Page. In a different way this is also a theme of our symposium on Terry Moe's Special Interest: Teachers Unions and America's Public Schools. Public schools are a central ingredient of a liberal democracy, and in recent years the declining quality of public education has been an important political theme, particularly in the US (see Joseph P. Viteritti's "Whose Equality? The Discouraging Politics of American Education (and What We Might Do About It)" in the September 2011 Perspectives). Terry Moe has long been an important contributor to public intellectual debates about public education and school choice, in a way that combines policy relevance with a refined "new institutionalist" perspective (see particularly his September 2005 Perspectives article on "Power and Political Institutions"). His Special Interest offers a provocative critique of US teachers' unions that is especially timely given current pressures being placed on state budgets and current arguments being made by a number of Republican politicians about the need to limit the power of public employee unions. In our symposium on his book we sought a diverse group of scholars with expertise on US education politics, public education and democratic theory, and labor movements in comparative perspective. The symposium features some spirited debate about questions both scientific and political, a testament to the importance of Moe's book and the issues it raises.

It is a truism of politics that economic inequality and social insecurity can weaken the social fabric and generate intolerance and resentment. As our September 2011 issue featuring "Immigration Politics" made clear, the politics of inclusion and exclusion remains a major challenge for liberal democracies. Our fourth research article, Matthew Wright and Irene Bloemraad's "Is There a Tradeoff Between Multiculturalism and Socio-Political Integration?" addresses this theme. Occasioned by the fact that "The turn away from multiculturalism and toward a more assimilationist discourse ... has become a full-fledged battle cry, driving the political success of anti-immigrant politicians like Geert Wilders in the Netherlands and the Sverigedemokraterna party in Sweden," the article employs cross-national survey data to empirically test whether multicultural policies and inclusionary citizenship laws contribute to social disintegration and a weakening of civic ties, as critics maintain, or to a stronger sense of integration among immigrant populations, as supporters maintain. They find that the strong claims of multiculturalism's critics are not born out by the evidence, and that "ultimately, immigrants seem to do best in countries combining open citizenship and multiculturalism." Their conclusion is worth quoting at length: "It is beyond the scope of our empirical analysis to offer a full-fledged normative critique of such a political outcome. But there are two things that we can say with confidence. The first is that the conventional public rationale for the move against multicultural policies-that they fail to promote civic integration-is false, at least as borne out by the kinds of survey data that we have analyzed. The second, which follows, is that repeal of such policies is likely to have the perverse effect of further marginalizing, and alienating, immigrant populations, to the detriment of both civic order and political legitimacy. We wonder whether this can be a good thing for the future of liberal democracy."

In Europe in particular, debates about multiculturalism increasingly turn on the role of Islamic immigrants and immigrant-based communities, and whether these groups are or are not consistent with a new and broader conception of "Europe," a cultural question heightened at the geopolitical level by Turkey's relationship to the EU. Behind these specific debates is an even broader question that is the thematic focus of our Book Review: the relationships between religion and politics, and the extent to which religion is a source of political inclusion or political antagonism or both. This is the principle theme of our symposium on Robert Putnam and David Campbell's American Grace: How Religion Divides and Unites Us. As Laura R. Olson notes in her commentary, "the core purpose of Putnam and Campbell's effort in American Grace is to sort out why a relatively peaceful religious pluralism manages to persistindeed, to thrive - in the United States, even in the face of religio-political polarization." Putnam and Campbell's analysis of religion as a source of American toleration and civic solidarity is usefully read alongside the Wright and Bloemraad article, and both together raise interesting comparative questions about the relationship between national religious histories and forms of political inclusion and political contestation.

Jack A. Goldstone raises similar questions in his "Is Islam Bad For Business?" a review essay on Timur Kuran's The Long Divergence: How Islamic Law Held Back The Middle East. Goldstone praises Kuran's preference for institutional analysis over any kind of cultural or religious essentialism. As he summarizes: "Kuran shows how Islamic law originally provided Middle Eastern states up to the Ottoman Empire with one of the most effective legal regimes to encourage commerce and industry that existed anywhere in the world. Yet built into those laws were a set of self-reinforcing characteristics that led away from the more complex, impersonal, and flexible organizational forms that came to characterize European commerce ... By the nineteenth century the Middle East lagged so far behind that the region's only way forward was to accept these legal and organizational forms, and seek ways to insert 
them into Islamic society." At the same time, Goldstone argues that Kuran exaggerates the historical role of Islamic law relative to the role of the state in shaping economic development. And he suggests that "there is a bit too much 'path dependence'" in Kuran's account. Goldstone's review is careful and tentative. At the same time, it offers not simply a critique of Kuran's historical thesis, but also a critique of the political pessimism that follows from it. As he writes: "If I am right, then Tunisia, Egypt, and even Libya have a better chance than Kuran thinks at achieving stable democracy. That is, if it was the historical strength of the state, and not the absence of corporate law and organizations, that has kept civil society weak in this region, then with the dictatorial regimes destroyed, these countries should be able to evolve fresh organizational forms rather quickly. Political parties, legislatures, constitutions, private businesses, NGOs, and religious associations should emerge or be strengthened in the aftermath of their revolutions." As in Turkey and Indonesia, Goldstone argues, the political changes currently unfolding in the Arab world admit many possible configurations of politics, economics, and Islam. Like Pateman, then, Goldstone regards democracy less as an outcome than as a process and a project. As the current occupations of public space in New York, Athens, and Cairo indicate, the meanings and consequences of this project remain very much in questionjust as the exploration of these themes remains a major preoccupation of political science scholarship.

On a more parochial note, this first issue of 2012 marks a number of developments here at Perspectives worth noting. The first is the departure of two terrific Editorial Assistants. Rebekah Tromble, who worked on articles for two years after working on the book review for two previous years, left Bloomington in September to take a position as Assistant Professor at the University of Leiden. As a result, Hicham Bou Nassif has now moved over to the articles section, and Rafael Khatchaturian has replaced him on the book review staff. December 2011 also marked the departure of Katie Scofield, who has worked indefatiguably on the articles section for the past two years, and is heading to Ecuador on a Mellon dissertation fellowship. Katie will be replaced by Beth Easter, an excellent advanced graduate student here at IU.

The second development worth noting is the addition of three new board members who in fact joined us in mid-2011 but have not yet been announced here. Henry Farrell, Mala Htun, and Mary Katzenstein each bring a unique set of skills and perspectives to our board, and we are thrilled to welcome them. We are also thrilled to note that our entire group of original editorial board members remains with our journal-a sign of their real commitment to our mission. Our board is an amazingly dedicated group, and we are fortunate to have them, one and all.

Finally, this issue marks the $10^{\text {th }}$ anniversary of our journal. Our upcoming September 2012 issue will com- memorate our journal's first decade by highlighting the range of valuable perspectives that political science can bring to bear on the controversial site of our association's 2012 annual conference. This special issue on "New Orleans, post-Katrina Recovery, and the Intersectional Future of American Cities," will include essays by my two editorial predecessors, Jennifer Hochschild and Jim Johnson, along with a range of articles, essays, symposia and reviews all dedicated to analyzing the announced theme. We are planning for this issue to be out prior to the APSA meeting, and intend for it to be the basis of our 2011 annual theme panel at APSA.

As I have explained before, we regard our effort to highlight themes in each issue as an important dimension of our journal's distinctive mission and editorial philosophy. The specific themes we highlight are selected by me in conversation with my very engaged staff and with editorial board members. Such a process of selection involves judgments of significance that are essential to the running of any serious journal and especially to this journal. One of the strengths of Andreas Schedler's article is that it makes clear the importance of judgment even to intellectual processes like empirical measurement that many political scientists tend to regard as "objective." Editorial processes involve even greater degrees of judgment. Decisions on the assignment of external reviewers and the interpretation and balancing of diverse reviews, as well as the determination of whether and when work is publishable, and how to schedule and package publications and to frame them in each issue, are very complicated. I make them reflectively and in continual conversation with others. All the same, I make them. It's my job. Sometimes such decisions are very difficult. A few readers have noted that Henry Brady's 2010 APSA Presidential Address on graphics in political science was not the lead piece in the June 2011 issue in which it appeared. While these addresses have traditionally appeared in the March issue, this manuscript was only finalized at the very last minute of our printer deadline for June. We were determined to publish the address as soon as possible. At the same time, our June issue had long been structured around the theme of democratization, and this required leading with the Coppedge and Gerring piece featured on our June cover. We were also constrained to run the 2011 Address in the (current) March 2012 issue. In order to balance these and other significant editorial considerations, we ran Professor Brady's important address in June as we did, and called attention to the piece's importance in the Editor Introduction. By juxtaposing the Brady address with the Coppedge and Gerring article on measuring democracy, we allowed these pieces to complement each other to the benefit the issue as a whole. In the editing of Perspectives on Politics few things are "automatic." This makes the job both continually challenging and intellectually exciting. 


\section{Statement of Mission and Procedures}

Perspectives on Politics seeks to provide a space for broad and synthetic discussion within the political science profession and between the profession and the broader scholarly and reading publics. Such discussion necessarily draws on and contributes to the scholarship published in the more specialized journals that dominate our discipline. At the same time, Perspectives seeks to promote a complementary form of broad public discussion and synergistic understanding within the profession that is essential to advancing scholarship and promoting academic community.

Perspectives seeks to nurture a political science public sphere, publicizing important scholarly topics, ideas, and innovations, linking scholarly authors and readers, and promoting broad reflexive discussion among political scientists about the work that we do and why this work matters.

Perspectives publishes work in a number of formats that mirror the ways that political scientists actually write:

Research articles: As a top-tier journal of political science, Perspectives accepts scholarly research article submissions and publishes the very best submissions that make it through our double-blind system of peer review and revision. The only thing that differentiates Perspectives research articles from other peer-reviewed articles at top journals is that we focus our attention only on work that in some way bridges subfield and methodological divides, and tries to address a broad readership of political scientists about matters of consequence. This typically means that the excellent articles we publish have been extensively revised in sustained dialogue with the editor-me-to address not simply questions of scholarship but questions of intellectual breadth and readability.

"Reflections" are more reflexive, provocative, or programmatic essays that address important political science questions in interesting ways but are not necessarily as systematic and focused as research articles. These essays often originate as research article submissions, though sometimes they derive from proposals developed in consultation with the editor in chief. Unlike research articles, these essays are not evaluated according to a strict, doubleblind peer review process. But they are typically vetted informally with editorial board members or other colleagues, and they are always subjected to critical assessment and careful line-editing by the editor and editorial staff.

Scholarly symposia, critical book dialogues, book review essays, and conventional book reviews are developed and commissioned by the editor in chief, based on authorial queries and ideas, editorial board suggestions, and staff conversations.

Everything published in Perspectives is carefully vetted and edited. Given our distinctive mission, we work hard to use our range of formats to organize interesting conversations about important issues and events, and to call attention to certain broad themes beyond our profession's normal subfield categories.

For further details on writing formats and submission guidelines, see our website at http://www.apsanet.org/ perspectives/ 